\title{
METODE PENELITIAN HUKUM NORMATIF DAN EMPIRIS: KARAKTERISTIK KHAS DARI METODE MENELITI HUKUM
}

\author{
Depri Liber Sonata \\ Fakultas Hukum Universitas Lampung
}

\begin{abstract}
The aim in this article is to determine the method of normative and empirical legal research with the typical characteristics of the methods of researching Law. The approach used qualitative methods through the study of literature. Based on the research findings and discussion, it can be concluded, first, science law (jurisprudence) and all sub-study with him in a large family study of the law, no matter how controversial as as a discipline independent and peculiar (sui generis), part from the humanities and social sciences, as well as natural science (exact) and social sciences which has had an undeniable place in the branches of science. Science of law must be recognized as having the research methods typical and unique, in terms of interest / usefulness to do a research in the field of law, both theoretical and practical, or of how to look at the science of law as a discipline prescriptive and applied, as well as from the point of view of human behavior relating to the existence of the law. Secondly, the penstudi law should realize the importance of legal research which is the authority, even advised not to leave, ie normative legal research / doctrinal, both from the point of view of the approach commom law system (statutes approach, case approach, historical approach, comparative approach and conceptual approach) as well as from the standpoint of research form the principles of law, the synchronization of legislation and others. which has been used as a handle by penstudi law in Indonesia and tend intended for academic interest. Third, the differences in conceptions, notions in the study of legal research in various law schools and high schools of law, especially for academic interest (thesis and dissertation), the main question is whether or not a uniformity is realized, or let it all by referring to the belief respective legal research on how it thinks best.
\end{abstract}

Keywords: Research Methods law, Legal Normative and Empirical

\section{abstrak}

Tujuan yang ingin dicapai dalam penulisan ini adalah untuk mengetahui metode penelitian hukum normatif dan empiris dengan karakteristik khas dari metode meneliti Hukum. Pendekatan yang digunakan kualitatif dengan menggunakan metode melalui studi kepustakaan. Berdasarkan hasil temuan 
penelitian dan pembahasan, maka dapat disimpulkan, Pertama, Ilmu hukum (jurisprudence) dan segala sub kajian yang mendampinginya di dalam keluarga besar kajian tentang hukum, terlepas dari kontroversinya sebagai sebagai suatu disiplin ilmu yang mandiri dan khas (sui generis), bagian dari ilmu humaniora maupun ilmu sosial, sebagaimana ilmu pengetahuan alam (eksakta) dan ilmu-ilmu sosial yang telah memiliki tempat yang tak terbantahkan di ranting-ranting pohon ilmu. Ilmu hukum harus diakui memiliki metode penelitian yang khas sekaligus unik, baik dilihat dari kepentingan/kegunaan dilakukannya suatu penelitian di bidang hukum, baik teoritis maupun praktis, atau dari cara melihat ilmu hukum sebagai disiplin yang bersifat preskriptif dan terapan, maupun dari sudut pandang perilaku manusia yang berkaitan dengan eksistensi hukum. Kedua, Para penstudi hukum seyogyanya menyadari arti pentingnya penelitian hukum yang menjadi otoritasnya, bahkan dihimbau untuk tidak meninggalkannya, yaitu penelitian hukum normatif/doktrinal, baik dari sudut pandang pendekatan commom law system (statutes approach, case approach, historical approach, comparative approach dan conceptual approach) maupun dari sudut pandang bentuk penelitian asas-asas hukum, sinkronisasi peraturan perundang-undangan dan lain-lain. yang selama ini dijadikan pegangan oleh para penstudi hukum di Indonesia dan cenderung dimaksudkan untuk kepentingan akademis. Ketiga, masalah perbedaan konsepsi-konsepsi, pengertian-pengertian di dalam studi tentang penelitian hukum diberbagai fakultas hukum dan sekolah tinggi hukum khususnya untuk kepentingan akademis (skripsi, tesis, dan disertasi), pertanyaan utamanya adalah perlu atau tidaknya suatu keseragaman itu diwujudkan, atau membiarkan itu semua dengan berpedoman kepada keyakinan masing-masing peneliti hukum mengenai cara yang dianggapnya paling baik.

\section{Kata Kunci: Metode Penelitian hukum, Hukum Normatif dan Empiris}

\section{A. Pendahuluan}

Perlu disadari ilmu hukum adalah ilmu yang sangatlah kompleks, mulai dari kajiannya filosofis, pengembangan keilmuannya baik teoritis maupun praktis, sampai kepada wujud konkret dari eksistesinya yang tidak lain didedikasikan kepada masyarakat berupa produk-produk hukum, solusi terhadap baik perkara hukum publik maupun perkara hukum privat yang ditemukan sehari-hari di tengah masyarakat, bahkan tidak jarang beraspek multidimensi, atau dengan kata lain ilmu hukum tanpa dukungan ilmu-ilmu lain terkadang tidak mampu menyelesaikan permasalahan hukum secara tuntas dan menyeluruh.

Kajian hukum yang filosofis misalnya, diawali dengan sulitnya mendefinisikan konsepsi hukum itu sendiri, tarik menarik antara pencapaian 
keadilan dan kepastian hukum di tengah-tengah masyarakat dan lain-lain. Secara garis besar sebagaimana yang telah digulirkan oleh doktrin hukum alam dan positivisme hukum. kemudian apakah fungsi hukum itu? hingga yang lebih konkret tentang bagaimana menjadikan hukum yang sesungguhnya diinginkan oleh masyarakat (responsive), valid, sekaligus efektif, dan lain-lain. ${ }^{1}$ Mengingat begitu sulitnya mendeskripsikan konsepsi hukum tersebut, maka tidak sedikit para filsuf hukum baik disadari maupun tidak telah terseret kedalam pembentukan mazhab atau aliran tertentu (school of thought) yang menurut pemikiran mereka dan para pendukungnya masing-masing dianggap paling rasional, empiris, bahkan ide-ide pemikirannya sampai kepada persoalan pemilihan nilai-nilai atau ideologi tertentu guna mencapai suatu kesamaan presepsi tentang konsepsi yang biasa disebut keadilan, moralitas, validitas, dan lain-lain. Sebagaimana pernyataan yang biasa diutarakan oleh para penstudi hukum untuk melihat fenomena ini:

"It is difficult to characterize jurisprudence; there are many rooms in its mansion. But broadly, we shall see it is concern with rulegoverned action, with the activities of officials such as judge and with the relationship between them and population of a given society". 2

Di sisi lain, para penstudi hukum juga menghadapi pertanyaanpertanyan yang kerap diajukan oleh para sesama penstudi hukum itu sendiri maupun para penstudi nonhukum, tentang bagaimanakah para penstudi hukum itu melakukan kegiatan penelitian guna memecahkan masalahmasalah hukum konkret seperti kekosongan hukum, konflik dan sengketa, dan lain-lain, maupun dalam upaya mengembangkan disiplin hukum itu sendiri atau dengan kata lain apakah metode penelitian yang dipergunakan oleh para penstudi hukum, guna memecahkan permasalahan hukum baik yang bersifat teoritis maupun praktis bahkan sampai dengan pertanyaan kritis bahwa apakah metode penelitian hukum tersebut ilmiah pertanyaan kritis ini dikaitkan dengan kajian filsafat ilmu demi mencari jawaban yang memuaskan bahwa ilmu hukum itu adalah salah satu dari bidang keilmuan yang selama ini biasa dikelompokan para ilmuwan. Namun, sebagai patokan awal untuk memahami permasalahan di atas, berikut kutipan pendapat Soerjono Soekanto sebagai salah seorang ahli hukum yang menaruh perhatian khusus terhadap penelitian hukum di Indonesia, melalui salah satu

\footnotetext{
${ }^{1}$ Lihat: Lord Lloyd of Hampstead and MDA Freeman, Lloyd's Introduction to Jursprudence, $5^{\text {th }}$ ed., (London: Stevens\&Sons, 1985). hlm. 4. " Jurisprudence involves the study of general theoritical questions about nature of law and legal system, about the relationship of law to justice and morality, and about social nature of law... a study of jurisprudence should encourage the student to question assumption and to develop a wider understanding of the nature and working of law".

${ }^{2}$ Ibid., hlm. 11.
} 
karyanya yang diberi judul "metode penelitian hukum normatif: suatu pengantar":

... oleh karena penelitian merupakan sarana (ilmiah) bagi pengembangan ilmu pengetahuan dan teknologi, maka metodologi penelitian yang diterapkan harus senantiasa disesuaikan dengan ilmu pengetahuan yang menjadi induknya. Hal ini tidaklah selalu berarti metodologi penelitian yang dipergunakan pelbagai ilmu pengetahuan pasti akan berbeda secara utuh. Akan tetapi setiap ilmu pengetahuan mempunyai identitas masing-masing, sehingga pasti akan ada pelbagai perbedaan. Demikian juga halnya dengan metodologi penelitian hukum yang mempunyai karakteristik khusus yang menjadi identitasnya, sehingga dapat dibedakan dari ilmuilmu pengetahuan lainnya. Bahkan sebagian ilmuwan nonhukum masih mempertanyakan tentang apakah penelitian hukum tersebut dapat dikualifikasikan sebagai penelitian ilmiah yang biasa dipredikatkan kepada bidang ilmu lain khususnya dalam bidangbidang ilmu alam (eksakta) maupun ilmu sosial. ${ }^{3}$

Permasalahan inilah yang ternyata menjadi salah satu penyebab pembahasan hukum dan metode kajiannya menjadi sangat menarik sekaligus menantang bagi para penstudi hukum untuk terus dikaji oleh para penstudinya maupun penstudi disiplin keilmuan lain untuk terus bersikap logis, kritis, analitis, sekaligus realistis.

Dikatakan menarik, mengingat ketepatan, relevansi, dan konsistesi pilihan metode dalam melakukan penelitian demi penelitian hukum akan sangat terkait dengan hasilnya, yang tentu saja tujuannya akan bermanfaat/berguna bagi masyarakat secara umum, seperti berupa karya ilmiah hukum, putusan hukum, maupun dalam bentuk pendapat hukum dan lain-lain, yang pada dasarnya semua itu merupakan produk karya tulis di bidang hukum yang di dalamnya terkandung argumentasi dan penalaran hukum dalam memecahkan permasalahan-permasalahan yang berkaitan dengan kasus hukum konkret maupun yang berkaitan dengan pengembangan bidang keilmuan hukum itu sendiri, dimana dalam penyajiannya antara produk hukum satu dengan yang lainnya membutuhkan metode yang khas atau tersendiri. Meskipun, bagi sebagian penstudinya hal ini justru membingungkan bahkan cenderung ada yang bersikap skeptis, sehingga tidak terlalu menghiraukan atau tidak menaruh perhatian terhadap hukum dan metode penelitian kajiannya.

Permasalahan yang agak konkret mengenai masalah ini di antaranya bahwa keberadaan metode penelitian hukum, khususnya berkaitan dengan

\footnotetext{
${ }^{3}$ Soerjono Soekanto dan Sri Mamudji, Penelitian Hukum Normatif; Suatu Tinjauan Singkat (Jakarta: RajaGrafindo Persada, 2001), hlm.1-2.
} 
pilihan tahapan-tahapan penelitian, sistematika penulisan serta teknik penulisan pada komunitas akademis, khususnya dalam membuat produk karya ilmiah hukum di setiap fakultas hukum di beberapa universitas maupun Sekolah Tinggi Hukum nampaknya cenderung tidak seragam, atau seperti pepatah mengatakan "dimana bumi dipijak disitu langit dijunjung". Bahkan yang lebih memperihatinkan bahwa peneliti (mahasiswa hukum) yang sedang berproses di dalam penulisan karya tulis ilmiah sebagai syarat untuk mendapatkan gelarnya, dihadapkan pada kenyataan "mengikuti selera pembimbing (supervisor) penelitiannya, dalam artian peneliti tidak dapat memikirkan, memilih, bahkan mempertahankan argumentasinya sendiri terhadap pilihan metode penelitian hukum yang akan digunakan di dalam penelitian yang notabene permasalahan penelitian berangkat dari ide peneliti itu sendiri, meskipun dalam pelaksanaannya di bawah bimbingan atau pengawasan para ahli yang dianggap lebih menguasai isu penelitian dan menekuni terhadap isu penelitian yang sama dengan penelitian yang sedang dilaksanakan. ${ }^{5}$

Disamping itu, hal penting yang mesti diingat oleh sumber daya manusia yang memiliki pengetahuan dan keterampilan pada salah satu bidang ilmu pengetahuan di mana hukum sebagai objek kajiannya, yang merupakan produk dari proses pembelajaran ilmu hukum di berbagai fakultas hukum maupun sekolah tinggi hukum, tentunya dituntut memiliki kemampuan dan keterampilan dalam memecahkan permasalahanpermasalahan hukum konkret maupun yang berkaitan dengan pengembangan ilmu hukum secara teoritis, baik dari aspek normatif maupun empiris/sosiologis yang menuntut penggunaan metode penelitian yang ilmiah maupun standar profesi dan hasil akhirnya dalam bentuk karya tulis hukum, terlepas dari predikat ilmiah dan tidak ilmiah.

Khusus untuk kemampuan dan keterampilan dalam memecahkan masalah hukum konkret, yang biasanya ditekuni oleh para sarjana hukum yang memilih berkarir sebagai praktisi hukum, yang pada kenyataannya kemampuan dan keterampilan membuat produk-produk hukum tertentu untuk kepentingan praktis tentunya kecenderungan pilihan terhadap jenis

\footnotetext{
${ }^{4}$ Lihat: C.F.G. Sunaryati Hartono, Penelitian Hukum di Indonesia Penelitian Hukum di Indonesia pada Akhir Abad ke-20 (Bandung: Penerbit Alumni, 1994), hlm.1-50.

Meskipun penelitian yang dilakukan oleh C.F.G. Sunaryati Hartono dkk. ini dilakukan pada tahun 1982, setidak-tidaknya dapat menjadi bukti ilmiah bahwa telah terjadi keragaman penafsiran dan arti pentingnya penelitian hukum oleh para penstudi hukum (dalam hal ini Indonesia) sejak dulu.

${ }^{5}$ Hal ini dibuktikan dengan kenyataan tentang suatu pernyataan yang berbunyi "pokoknya normatif" atau " ini harus penelitian empiris" tanpa memberikan penjelasan, mengapa normatif dan mengapa harus empiris?
} 
penelitian hukum normatif/doktrinal tentunya lebih dominan jika dibandingkan dengan jenis penelitian hukum empiris/sosiologis. ${ }^{6}$

Namun demikian, konsep maupun jenis penelitian normatif dan sosiologis sebagaimana dikenal di dalam khasanah penelitian hukum (dalam hal ini Indonesia) masih merupakan permasalahan yang cukup sulit untuk diidentifikasikan. Tulisan sederhana ini mencoba mendiskusikan hal-hal tersebut sebagai sumbangan pemikiran yang dapat didedikasikan untuk sebuah identitas dari kajian ilmu hukum.

\section{B. Pembahasan}

\section{Penelitian Hukum (Legal Research) dan Penulisan Hukum (Legal Writing).}

Para penstudi hukum tidak terlepas dari rutinitas yang berkaitan dengan penulisan hukum (legal writing), sedangkan untuk melakukan penulisan hukum tersebut dibutuhkan suatu penelitian hukum (legal research) dalam arti secara umum. Tentunya sangat penting melihat hubungan antara penelitian hukum dan produk-produk penulisan hukum, jika kita ingin melihat penelitian hukum dari sudut pandang kegunaannya (purposes) bukan pada metode dan jenis-jenis pendekatannya. Berdasarkan kegunaannya tersebut dapat dibedakan menjadi 2 (dua), yaitu untuk kepentingan praktek hukum dan untuk kepentingan akademis, dan yang bersifat praktis maupun teoritis. Di bawah ini dapat dilihat tabel bentukbentuk produk penulisan hukum tersebut.

\begin{tabular}{|c|c|c|c|}
\hline \multicolumn{2}{|r|}{$\mathbf{A}$} & \multicolumn{2}{|r|}{ B } \\
\hline No. & Kepentingan Akademis & No. & Kepentingan Praktek \\
\hline 1. & Makalah (paper) & 1. & $\begin{array}{l}\text { Memorandum hukum (legal } \\
\text { memorandum/memoranda of law). }\end{array}$ \\
\hline 2. & Laporan & 2. & Pendapat Hukum (legal opinion). \\
\hline 3. & Penelitian & 3. & $\begin{array}{l}\text { Nota Pembelaan hukum di } \\
\text { pengadilan }(\text { Pledoi }) .\end{array}$ \\
\hline 4. & Skripsi & 4. & $\begin{array}{l}\text { Ringkasan dan analisis putusan } \\
\text { hakim terdahulu (court brief,diggest). }\end{array}$ \\
\hline 5. & Tesis (thesis) & 5. & Penulisan untuk penyuluhan hukum. \\
\hline 6. & $\begin{array}{l}\text { Disertasi (thesis of } \\
\text { Doctoral) }\end{array}$ & 6. & $\begin{array}{l}\text { Perancangan undang-undang } \\
\text { (legislative drafting). }\end{array}$ \\
\hline
\end{tabular}

\footnotetext{
${ }^{6}$ Meskipun pernyataan ini tidak didukung oleh bukti statistik dari hasil penelitian ilmiah tertentu, setidak-tidaknya dapat dijadikan hipotesis guna membuktikan kebenarannya.
} 


\begin{tabular}{|c|c|c|c|}
\hline \multirow[t]{2}{*}{7.} & $\begin{array}{lr}\text { Artikel } & \text { untuk majalah } \\
\text { ilmiah } & \text { hukum/jurnal } \\
\text { hukum } & \text { (essay) dan lain- }\end{array}$ & 7. & $\begin{array}{l}\text { Perancangan kontrak dan } \text { Akta } \\
\text { Notaris (contract drafting, deed } \\
\text { drafting). }\end{array}$ \\
\hline & & 8. & $\begin{array}{l}\text { Penulisan instrumen-instrumen } \\
\text { hukum/surat-surat resmi hukum } \\
\text { (legal forms, legal letters). } \\
\text { Uji tuntas/audit hukum (legal due } \\
\text { diligence) dan lain-lain. }\end{array}$ \\
\hline
\end{tabular}

\section{Meneliti Hukum Sebagai Kegiatan Ilmiah}

Pertanyaan mengenai apakah metode penelitian hukum itu ilmiah? sama filosofisnya dengan pertanyaan apakah ilmu hukum itu dapat dikategorikan suatu ilmu yang kadar keilmiahannya dapat disejajarkan dengan ilmu-ilmu sosial bahkan dengan ilmu-ilmu alam? namun demikian faktanya adalah para penstudi hukum ternyata memiliki sistem dan metode penelitian tersendiri yang khas, dan berkembang seiring dengan perkembangan kajian hukum itu sendiri.

The role of law is to bring order to chaos and to ease societal pressures, but most student and faculty feel a sense of chaos and pressures when learning to do legal research. This is natural. Legal research is different from research in other disciplines, it has different vocabulary, different form of laws, and different jurisdiction of authority and hierarchies of importance; and there never seems to be definitive answer. ${ }^{7}$

Ciri khas sebagaimana di maksud juga didasarkan pada fakta bahwa meneliti hukum tidak hanya berhubungan dengan fakta-fakta hukum, peraturan-peraturan hukum, kasus-kasus hukum terdahulu, buku-buku hukum, dan lain-lain yang dapat dijadikan referensi di dalam melakukan penelitian hukum murni (purely legal research), melainkan perilaku individu-individu dalam masyarakat juga pada kenyataanya dapat digunakan di dalam penelitian hukum kontemporer yang diilhami oleh ilmu hukum perilaku (behavioral jurisprudence), yang sering juga disebut dengan penelitian hukum empiris/sosilogis/nondoctrinal/socio-legal. Sedangkan apa yang menyebabkan adanya dua jenis penelitian di dalam bidang hukum ini (normatif dan empiris) akan dibicarakan dalam bahasan tersendiri kemudian, yaitu pengaruh perkembangan pemikiran para filsuf hukum (legal philoshopers) yang dikumpulkan di dalam sebuah kajian yang dinamakan dengan jurisprudence, di mana "Jurisprudence as the accumulated wisdom

\footnotetext{
${ }^{7}$ Colleen Kristl Pauwels, Linda K. Fariss, Keith Buckley, Legal Research: Traditional Sources, New Technologies (USA: Phi Delta Kappa International, 1999), hlm.3.
} 
of great thingkers of the past...", terhadap perkembangan dan pilihan metode penelitian hukum yang sesuai.

\section{a. Memaknai Kata "peneltian" dalam Ungkapan "Penelitian Hukum"}

C.F.G. Sunaryati Hartono menegaskan bahwa:

"Bagaimanapun juga, metode penelitian selalu mencari titik-titik tolak yang pasti dan peraturan-peraturan penelitian yang diharapkan tentang bagaimana suatu penelitian harus dilakukan supaya dapat menghasilkan kesimpulan yang dapat dipertanggungjawabkan (reliable) dan sahih (valid)".9.

Di sisi lain William H. Putman di dalam bukunya yang berjudul Legal Research, Analysis and Writing berpendapat bahwa: ... So what do we mean by "research"? we do not mean experiments which scientists tend to mean by "research". The word research means "to find things out". ${ }^{10}$

Kemudian, setelah kita mengetahui bahwa produk-produk karya tulis hukum sebagaimana disebutkan di atas tidak hanya untuk kegunaan atau bersifat teoritis maupun akademis, melainkan juga ada yang dikategorikan untuk kegunaan dan bersifat praktis, maka tentunya kita tidak menyangkal bahwa di dalam pembuatan produk-produk karya tulis hukum untuk kegunaan dan bersifat praktis, yang biasanya ditekuni oleh para praktisi hukum tersebut, juga merupakan kegiatan penelitian (bukan eksperimen seperti yang dilakukan ilmuwan eksakta) dan membutuhkan metode-metode khusus dalam pelaksanaan dan penyajiannya, ${ }^{11}$ bahkan tujuan akhirnya tidak lain untuk mendapatkan klarifikasi dari pertanyaan maupun permasalahan hukum tertentu. Dalam hal ini tentunya timbul pertanyaan dapatkah kegiatan penelitian seperti itu dikategorikan sebagai penelitian hukum?

Namun demikian, tidak sedikit para penstudi hukum yang beranggapan bahwa penelitian hukum hanya merupakan wilayah otoritas para penstudi hukum yang berprofesi sebagai akademisi mupun peneliti hukum saja, yang produk akhirnya berupa skripsi, tesis, disertasi, artikel jurnal ilmiah dan laporan penelitian di bidang hukum, dan lain-lain.

Oleh sebab itu, bila diartikan secara luas maka, aktifitas meneliti hukum tentunya sadar maupun tidak telah menjadi rutinitas bagi para pengemban profesi-profesi hukum, baik peneliti, akademisi, maupun praktis,

\footnotetext{
${ }^{8}$ Lloyd, Op. Cit., hlm. 16.

${ }^{9}$ C.F.G. Sunaryati Hartono, Penelitian Hukum di Indonesia Penelitian Hukum di Indonesia pada Akhir Abad ke-20 (Bandung: Penerbit Alumni, 1994), hlm. 108.

${ }^{10}$ William H. Putman, Legal Research, Analysis and Writing (Australia: Thomson Delmar Learning, 2004), hlm. 27.

11 Dalam konteks ini makna " penelitian" tentunya harus dibedakan dengan kategori penelitian ilmiah yang biasa dilakukan oleh para penstudi maupun peneliti di bidang ilmuilmu nonhukum (logico-hypothetico-verivicatie).
} 
bahkan ilmuwan dari disiplin ilmu di luar hukum, dan tentunya dengan menggunakan metodenya yang khas pula.

\section{b. Makna Kata "Metode" dalam Ungkapan "Metode Penelitian Hukum"}

Kata metode yang biasanya disandingkan dengan frase penelitian hukum, tentunya dapat diinterpretasikan luas, apakah yang dimaksud adalah metode ilmiah atau metode hanya sebagai "cara", sebagaimana makna gramatikalnya

Setelah kita sepakat bahwa penelitian hukum sebagaimana telah disebutkan di atas dapat diartikan secara luas, namun terhadap bidang profesi hukum tertentu, bahkan mahasiswa hukum yang kesemuanya adalah penstudi hukum harus tunduk pada suatu otoritas individu maupun lembaga yang ada maupun tidak ada dasar maupun mengejar tujuan tertentu dihadapkan pada kategorisasi "penelitian hukum" yang didasarkan oleh aturan main tersendiri yang disepakati antara peneliti dan lembaga yang dimana hasil penelitian tersebut akan didedikasikan.

\section{Pengaruh Perkembangan Pemikiran Tentang Hukum terhadap Jenis Penelitian Hukum}

Filsafat hukum merupakan cabang dari ilmu filsafat, sedangkan teori hukum merupakan disiplin mandiri (autonomous discipline) dari ilmu hukum. Pembagian jenis penelitian hukum, antara normatif dan empiris yang dikenal oleh para peneliti hukum ternyata juga dipengaruhi oleh perkembangan hasil pemikiran tentang hukum oleh para filsuf hukum (legal philosopher) yang biasa dipelajari di dalam kajian filsafat hukum maupun teori hukum (Jurisprudence). Sebagaimana diketahui bahwa perkembangan pemikiran tentang konsep-konsep hukum dan dinamikanya diawali oleh aliran/mazhab hukum alam (natural law), positivisme hukum (legal positivism), realisme hukum (legal realism), dan lain-lain. hingga sampai kepada pemikiran-pemikiran hukum post mederenism dan law and economic atau economic analysis of law. Namun, dua kelompok aliran besar yang sangat mempengaruhi perkembangan penelitian hukum, sehingga melahirkan dua jenis penelitian hukum (normatif dan empiris) yaitu: pertama, aliran/mazhab (school of thought) yang pokok-pokok pemikirannya berlandaskan pada ide-ide positivisme hukum (legal positivism, legal realism, pure theory of law, dan lain-lain.) dan kedua, aliran/mazhab yang pokok-pokok pemikirannya berlandaskan pada ide-ide hukum yang bersifat sosiologis (sociological jurisprudence, sociology of law, critical legal studies, dan lain-lain). Dengan demikian disinilah yang menjadikan penelitian hukum sering dikatakan memiliki ciri yang khas dibandingkan 
dengan penelitian dalam bidang ilmu alam bahkan penelitian dalam bidang ilmu sosial yang bahkan memiliki kesamaan dengan salah satu jenis penelitian hukum yaitu penelitian hukum empiris/sosiologis/socio-legal.

Metode penelitian hukum dalam konteks keilmuan hukum dan metode penelitian hukum dalam konteks penemuan dan penerapan hukum, dalam konteksnya yang pertama, pada umumnya dilakukan oleh peneliti hukum akademis ini, memiliki dua jenis penelitian hukum yaitu: penelitian hukum normatif dan penelitian hukum sosiologis. Penelitian hukum normatif dipengaruhi oleh doktrin hukum murni dan positivisme, sedangkan penelitian hukum sosiologis dipengaruhi oleh doktrin sosiologi hukum (sosiologi of law) maupun ilmu hukum sosilogis (sociological jurisprudence)

Ilmu hukum termasuk ke dalam kategori ilmu humaniora, seni, bahkan memiliki keterkaitan dengan filsafat dan sastra, dengan demikian dapat dibedakan dengan bidang-bidang ilmu alam dan ilmu sosial. Namun demikian, pengaruh ilmu sosial terhadap disiplin hukum harus tetap diakui oleh para penstudi hukum telah memberikan kontribusi sekaligus telah sedikit banyak mengintervensi perkembangan pemikiran maupun metode penelitian hukum. Mengingat perkembangan pemikiran tentang hukum yang sosiologis telah membuka peluang baru untuk para peneliti hukum dalam meneliti hukum dengan tidak hanya melihat hukum secara dogmatis dan ekslusif dari sentuhan disiplin ilmu-ilmu lain, melainkan membuka peluang untuk melakukan penelitian hukum secara multidisiplin, sehingga memungkinkan melihat hukum pada alam empiris yang tidak lain berada di tengah masyarakat, tempat di mana hukum itu dianggap sebagai fenomena sosial yang dinamis dan saling berinteraksi dengan fenomena sosial lainnya seperti ekonomi, politik, dan lain-lain.

\section{Jenis-Jenis Penelitian Hukum}

Apakah penelitian hukum normative/doktrinal dan empiris/nondoktrinal benar-benar berbeda atau dapat diharmonisasikan dalam suatu kegiatan penelitian hukum pertanyaan ini didasarkan pada fenomena perbedaan pendapat para penstudi hukum di Indonesia. Soerjono Soekanto ${ }^{12}$ berpendapat bahwa penelitian hukum normatif dan empiris dapat dilakukan terpisah maupun secara bergabung, namun ada pula penstudi hukum yang memisahkan secara tegas antara keduanya, namun ada pula yang menghargai perbedaan kedua jenis penelitian tersebut namun secara persuasif menghimbau para penstudi hukum untuk kembali kepada penelitian hukum yang murni menjadi otoritas penstudi hukum itu sendiri. Tolok ukur analisis yang akan digunakan adalah melihat perbedaan dua jenis

\footnotetext{
${ }^{12}$ Soerjono Soekanto, Op. Cit., hlm. 6.
} 
penelitian hukum tersebut di atas dari aspek pendekatan, tujuan, dan jenis data yang digunakan.

\section{a. Penelitian Hukum Normatif/Doctrinal Legal Research}

Tolok ukur Soerjono Soekanto dalam pembahasannya mengenai penelitian hukum normatif adalah dari sifat dan ruang lingkup disiplin hukum, dimana disiplin diartikan sebagai suatu sistem ajaran tentang kenyataan, yang biasanya mencakup disiplin analitis dan disiplin preskriptif, dan disiplin hukum lazimnya termasuk ke dalam disiplin preskriptif jika hukum dipandang hanya mencakup segi normatifnya saja. Namun demikian, masih di dalam tulisannya yang sama tersebut, Soerjono Soekanto tetapi ingin membuktikan dan menegaskan bahwa disiplin hukum lazimnya juga dapat diartikan sebagai suatu sistem ajaran tentang hukum sebagai norma dan kenyataan (perilaku) atau sebagai sesuatu yang dicita-citakan dan sebagai realitas/hukum yang hidup, bahkan disiplin hukum tersebut memiliki segi umum dan khusus. ${ }^{13}$

Selanjutnya dipaparkan juga bahwa sifat dari dogmatik hukum (ilmu tentang kaidah hukum dan ilmu tentang pengertian pokok dalam hukum) bersifat teoritis-rasional dan model penalaran yang digunakan adalah logikadeduktif, sedangkan ilmu tentang kenyataan hukum (sosiologi hukum, antropologi hukum, psikologi hukum, perbandingan hukum, dan sejarah hukum) bersifat teoritis-empiris dan model penalaran yang digunakan adalah logika induktif. Filsafat hukum bersifat etis-spekulatif dan politik hukum bersifat praktis fungsional.

Berbeda dengan jenis penelitian hukum empiris, penelitian hukum normatif memiliki kecenderungan dalam mencitrakan hukum sebagai disiplin preskriptif di mana hanya melihat hukum dari sudut pandang normanormanya saja, yang tentunya bersifat preskriptif. Dimana tema-tema penelitiannya mencakup: ${ }^{14}$

1) Penelitian terhadap asas-asas hukum;

2) Penelitian terhadap sistematika hukum;

3) Penelitian terhadap taraf sinkronisasi vertical dan horizontal;

4) Perbandingan hukum; dan

\section{${ }^{13}$ Ibid., hlm. 2-6.}

Disiplin hukum mencakup segi umum dan khusus, segi umum disiplin hukum yaitu ilmu hukum (jurisprudence), filsafat hukum dan politik hukum. Sedangkan segi khusus disiplin hukum yaitu: sejarah tata hukum, sistem tata hukum yang menyangkut bidang-bidang hukum tertentu; teknologi hukum atau keterampilan hukum.

${ }^{14}$ Ibid., hlm. 14.

Secara tegas Soerjono Soekanto mengidentikan penelitian hukum normatif dengan penelitian hukum kepustakaan jika dilihat dari sumber data yang relevan pada penelitian jenis ini. 
5) Sejarah hukum.

Di lihat dari segi jenisnya yang sangat doktrinal atau normatif, penelitian hukum normatif yang ada di Indonesia mirip dengan penelitian hukum common law, dimana penelitian hukum di dalam sistem hukum common law lebih berorientasi kepada aspek praktis, yaitu biasanya untuk menyelesaikan masalah hukum konkret (perkara hukum tertentu) dan dilakukan oleh para praktisi hukum (legal practitioners) baik bentuknya sengketa maupun hanya ingin mencari bagaimana dan di mana suatu permasalahan hukum tersebut diatur oleh hukum yang dilakukan melalui penelitian fakta-fakta hukum, peraturan hukum yang relevan bahkan juga melihat kasus-kasus yang relevan dengan pertanyaan yang ingin dipecahkan. ${ }^{15}$

Legal research is the process of locating the law that applies to the question raised by the facts of the case. Legal research and analysis are interrelated, and performing legal research usually involves the use of analysis principles. ${ }^{16}$ The object of legal analysis and legal research are to analyze the factual event presented by the client and determine: what is the legal issue (question) or issues raised by the factual event;

1) What law govern the legal issue;

2) How the law that governs the legal issue applies to the factual event, including what, if any legal remedy is available. ${ }^{17}$

Sedangkan di dalam penelitian hukum tersebut metode penelitian atau langkah-langkah analisis yang dilakukan mengacu kepada metode IRAC (issue, rule, analysis/application, conclusion) atau lebih jelasnya adalah sebagai berikut: ${ }^{18}$

Step 1:

Issue, the identification of the issue (legal question) or issues raised by the facts of the client case.

Step 2:

Rule, the identification of the law that governs the issue;

Step 3:

Analysis/application, a determination of how the rule of law applies to the issue;

Step 4:

Conclusion, a summary of the results of the legal analysis.

Sedangkan hal-hal yang perlu dipersiapkan sebelum melakukan analisis kasus/pertanyaan hukum adalah:

\footnotetext{
${ }^{15}$ William H. Putman, Legal Research, Analysis and Writing (Australia: Thomson Delmar Learning, 2004), hlm.

${ }^{16}$ Ibid., hlm. 47.

${ }^{17}$ Ibid., hlm. 26.

${ }^{18}$ Ibid., hlm. 26-27.
} 
1) All the facts and information relevant to the case should be gathered; and

2) Preliminary legal research should be conducted to gain a basic familiarity with the area of law involved in the case.

Penegasan tentang pentingnya fakta-fakta hukum di dalam melakukan analisis hukum, di mana dari setiap tahapan IRAC sebagaimana telah disebutkan di atas unsur ini memegang peranan yang sangat penting (The crucial role facts play in the analytical process). Hal ini mengingat bahwa proses analisis hukum untuk menentukan hukum apa yang relevan dengan fakta-fakta hukum yang ditemukan atau dengan kata lain, In every case, the analytical process involves a determination how the law applies to the facts. In the court opinion, courts determine how the law applies to the facts presented to the court. ${ }^{19}$

\section{b. Penelitian Hukum Empiris (empirical legal research) atau Penelitian Socio-legal (Socio-Legal Research)}

Pengaruh ilmu sosial terhadap disiplin hukum adalah kalimat kunci yang sesuai sebagai pembuka pembicaraan mengenai jenis penelitian yang satu ini, yaitu penelitian hukum empiris ${ }^{20}$ (empirical legal research). Kata "empiris" bukan berarti harus menggunakan alat pengumpul data dan teoriteori yang biasa dipergunakan di dalam metode penelitian ilmu-ilmu sosial, namun di dalam konteks ini lebih dimaksudkan kepada pengertian bahwa "kebenarannya dapat dibuktikan pada alam kenyataan atau dapat dirasakan oleh panca indera" atau bukan suatu fiksi bahkan metafisika atau gaib, yang sejatinya berupa proses berfikir yang biasanya hanya dongeng maupun pengalaman-pengalaman spiritual yang diberikan Tuhan tidak kepada setiap manusia dan tidak harus melalui proses penalaran ilmiah suatu hal tertentu dapat diterima kebenarannya, meskipun oleh para ilmuwan kadang dikatakan tidak ilmiah atau an illogical phenomena. Penerimaan terhadap suatu yang bersifat ilmiah biasanya dipredikatkan dengan ungkapan "masuk akal", sedangkan penerimaan terhadap suatu yang bersifat metafisika dan spiritual biasanya disebut sebagai kepercayaan.

\footnotetext{
${ }^{19}$ Ibid., hlm. 27.

${ }^{20}$ Pengistilahan konsep "Penelitian Hukum Empiris" masih dipertahankan sampai saat ini di beberapa fakultas hukum di Indonesia, khususnya Fakultas Hukum Universitas Indonesia, dan tetap mengacu kepada buku referensi untuk melakukan penelitian hukum yang berjudul "Pengantar Penelitian Hukum" ditulis oleh Soerjono Soekanto. Mungkin mengingat bahwa beliau adalah seorang sarjana hukum dan Master of Art dibidang sosiologi maka wajar jika banyak tulisan-tulisannya yang berkaitan dengan hukum dan masyarakat/sosiologi hukum, karena beliau salah satu peletak dasar perkembangan disiplin tersebut berikut pengaruhnya dalam memperkenalkan metode penelitian hukum di hampir semua fakultas hukum di Indonesia.
} 
Oleh sebab itu, penelitian hukum empiris dimaksudkan untuk mengajak para penelitinya tidak hanya memikirkan masalah-masalah hukum yang bersifat normatif (law as written in book), bersifat teknis di dalam mengoperasionalisasikan peraturan hukum seperti mesin yang memproduksi dan menghasilkan hasil tertentu dari sebuah proses mekanis, dan tentunya hanya dan harus bersifat preskriptif saja, meskipun hal ini adalah wajar, mengingat sejatinya sifat norma hukum yang "ought to be" itu. Selanjutnya cara pandang sebagaimana disebutkan tadi bergeser menuju perubahan ke arah penyadaran bahwa hukum, faktanya dari perspektif ilmu sosial tenyata lebih dari sekadar norma-norma hukum dan teknik pengoperasiannya saja, melainkan juga sebuah gejala sosial dan berkaitan dengan perilaku manusia ditengah-tengah kehidupan bermasyarakat yang unik dan memikat untuk diteliti tidak dari sifatnya yang preskriptif, melainkan bersifat deskriptif.

Di sisi lain, mengingat para penstudi hukum sejatinya tidak terlatih melakukan penelitian sebagaimana dimaksud, dan faktanya memang tidak dipersiapkan untuk itu, maka peranan para ilmuan sosial berikut metodemetode penelitian bahkan teori-teorinya dibutuhkan oleh sebagian penstudi hukum yang ingin melakukan penelitian di bidang hukum dengan menggunakan pendekatan ilmu sosial (socio-legal research ${ }^{21}$ ) maupun disebut dengan penelitian hukum interdisipliner, karena kadang-kadang bersentuhan dengan ilmu ekonomi, antropoligi, bahkan ilmu politik dan lainlain.

Penelitian hukum normatif/doktrinal yang di dalam literatur hukum asing biasa disebut dengan legal research dan tanpa tambahan makna lain, menurut sebagian penstudi hukum dikatakan sebagai penelitian hukum yang murni (the pure legal research). ${ }^{22}$ Mengapa demikian Hal ini disebabkan oleh kenyataan bahwa disamping penelitian hukum yang murni sebagaimana telah diuraikan di atas masih terdapat jenis penelitian lain yang mendampinginya dan biasa dipelajari oleh para penstudi hukum di bawah judul kuliah "Metode Penelitian Hukum" (dalam hal ini di Indonesia khususnya), dan mungkin kenyataan ini yang menjadikan penelitian hukum dikatakan sebagai penelitian yang khas.

\footnotetext{
${ }^{21}$ Perkembangan penggunaan istilah Socio-legal research/penelitian hukum nondoctrinal diperkenalkan oleh para penstudi hukum Universitas Airlangga (Soetndyo W.) dan Universitas Diponegoro (Satjipto Rahardjo), keduanya dikenal sebagai peletak dasar dan masih eksis dalam bidang hukum dan masyarakat/socio-legal studies. Sebagaimana Mochtar Kusumaatmadja di UNPAD yang dipandang sebagai peletak dasar doktrin Roscoe Pound di Indonesia.

${ }^{22}$ Pendapat ini tidak hanya diyakini oleh para penstudi hukum di Indonesia, namun hampir di seluruh belahan dunia khususnya pada common law tradition yang kerap mensinonimkan legal research dengan langkah-langkah memecahkan masalah hukum konkret yang biasanya dengan model analisis IRAC (Issue, Regulation, Analysis, Conclusion).
} 
Jenis penelitian yang dimaksud adalah penelitian hukum empiris atau socio-legal (Socio legal research) yang merupakan model pendekatan lain dalam meneliti hukum sebagai objek penelitiannya, dalam hal ini hukum tidak hanya dipandang sebagai disiplin yang preskriptif dan terapan belaka, ${ }^{23}$ melainkan juga empirical atau kenyataan hukum.

Basis perkembangan socio legal research di United Kingdom/UK ternyata berada di fakultas-fakultas hukum (law school) dan ditekuni oleh para penstudi hukum, bukan di fakultas-fakultas ilmu sosial (social science), meskipun socio legal study sangat erat kaitannya dengan kajian sosiologi hukum (sociology of law). ${ }^{24}$ Socio legal study merupakan studi hukum interdisipliner maupun salah satu pendekatan dari penelitian hukum ( $a$ methodological approach) yang bahkan terkesan bertolak belakang sekali dari kajian hukum yang sifatnya doktrinal. Socio-legal tidak disamakan dengan legal sociology di negara-negara Eropa Barat, bahkan law and sociology scholarship di USA, di mana peranan ilmu sosiologi lebih dominan dalam kajiannya. "Socio". Dan di dalam socio-legal studies tidak mengacu kepada ilmu sosiologi maupun ilmu-ilmu sosial, melainkan "an interface with a context within which law exist" ${ }^{25}$ oleh sebab itu, mengapa di saat para peneliti socio-legal menggunakan teori-teori sosial tertentu sebagai alat bantu analisis tidak diarahkan untuk menjadi kajian ilmu sosiologi dan ilmu sosial lainnya, melainkan diarahkan untuk kajian ilmu hukum. Namun ilmu sosiologi dan ilmu-ilmu sosial lainnya, bagi socio-legal studies sangat diperlukan peranannya yaitu guna meminta/memperoleh data-data saja, hal ini sangat beralasan mengingat bahwa ilmu sosiologi misalnya, memiliki karakteristik yang deskriptif dan kategoris.

Socio-legal research is, in some respects, founded on a paradox in that, while it claims or aspires to be an interdisciplinary subject with particular ties with sociology, the majority of its practitioners are based in law schools, and have no received any systematic training in either sociological theory and research methods. ${ }^{26}$

\footnotetext{
${ }^{23}$ Banakar, Reza and Max Traves (editor). Theory and Method in Socio-Legal Research: A Series published for The ONATI institute for the sociology of law (Oxford and Portland Oregon: Hart Publishing, 2005), hlm.

${ }^{24} \mathrm{Di}$ antaranya University of Oxford, dengan nama "Socio-Legal Studies", Lihat situs: http://www.admin.ox.ac.uk/postgraduate/caz/socleg.shtml. lihat juga : University College London (UCL) dengan nama " Center for Empirical Legal Studies", lihat alamat situs: http://www.ucl.ac.uk/laws/socio-legal/index.shtml. Lihat juga: Lancaster University Law School di alamat situs: http://www.lancs.ac.uk/fass/law/prospective/postgrad/sociolegal.htm. dan masih banyak lagi.

${ }^{25}$ S Wheeler dan PA Thomson, Socio-legal Studies, di dalam DJ. Hayton, (ed), Laws futures (Oxford: Hart Publishing,2002) hlm. 271. sebagaimana dikutip oleh: Banakar, Ibid., hlm. xii.

${ }^{26}$ Ibid., hlm. 1.
} 
Berbeda dengan penelitian hukum normatif yang lebih dulu ada di tengah-tengah keluarga besar disiplin hukum, socio-legal research biasanya dikembangkan dalam suatu lembaga-lembaga independen, seperti di Indonesia misalnya: ELSAM dan HUMMA. Sedangkan di Negara lain seperti Inggris misalnya lembaga tersebut juga ada yang independen maupun berada di bawah naungan law school atau faculty of law, seperti: University College London (UCL) School of Law UK dengan The Centre for Empirical Legal Studies-nya. Di mana maksud dan tujuannya lembaga tersebut adalah: ${ }^{27}$

“...to bring together experts across a range of social science disciplines to engage in interdisciplinary research with a bearing on law. The Centre's ambitions are to be a world leader of methodological innovation in empirical legal studies, to build research capacity in the United Kingdom and to promote the evidence led evolution of justice systems around the world.

Sedangkan bidang-bidang penelitiannya adalah: ${ }^{28}$

"The emphasis of the work of the centre is on interdisciplinary empirical research investigating the operation and effects of law within the context of the social, economic and political environment. The work of the centre is concerned with the role and function of law, the enforcement of law, compliance with law, resistance to law, the use and experience of law, the impact of law and the character of law itself'.

\section{Mengenai Data dalam Penelitian Hukum}

Dari sudut pandang jenis-jenis data yang dipergunakan di dalam penelitian hukum, penelitian hukum normatif sering disinonimkan dengan penelitian kepustakaan (library research) jika dilihat atas kecenderungannya dalam menggunakan dokumen-dokumen sebagai bahan penelitiannya, sedangkan penelitian hukum empiris kerap disinonimkan dengan penelitian lapangan (field research) dilihat dari kecenderungannya dalam menggunakan data-data primer. ${ }^{29}$

Apakah penelitian normatif tidak boleh menggunakan alat pengumpul data maupun bahan-bahan hukum selain melalui studi kepustakaan? Apakah penelitian hukum empiris/nondoktrinal/socio-legal research harus menggunakan alat pengumpul data seperti yang dipergunakan oleh ilmuilmu sosial seperti: pengamatan/observasi, wawancara/interview, survey,

\footnotetext{
${ }^{27}$ University College London (UCL) dengan nama “ Center for Empirical Legal Studies" lihat pada alamat situs: http://www.ucl.ac.uk/laws/socio-legal/index.shtml.

${ }^{28}$ Loc.cit.

${ }^{29}$ S. Soekanto., Op.Cit, hlm. 13-14.
} 
kuesioner, dan metode analisis statistik sosial (distribusi, korespondensi, dan lain-lain.)? apakah ada akibatnya terhadap validitas dan tujuan hasil penelitian yang dilakukan?

Hampir semua jenis penelitian memerlukan studi pustaka, walaupun para peneliti sering membedakan antara riset pustaka dan riset lapangan. Namun demikian, faktanya adalah bahwa kedua jenis penelitian di atas tetap membutuhkan penelusuran pustaka. Perbedaan antara kedua jenis ini terletak pada tujuan, fungsi, dan atau kedudukan studi pustaka dalam masing-masing penelitian.

Pada riset lapangan (field research) penelsuran pustaka dibutuhkan pada saat menyusun kerangka penelitian (research design) dan atau proposal guna memperoleh informasi awal dari penelitian terdahulu yang lebih kurang sejenis, untuk memperdalam teori yang mungkin akan digunakan, maupun untuk memperdalam pengetahuan peneliti tentang metode yang akan digunakan.

Pada konteks penelitian hukum murni atau penelitian hukum normatif/doktrinal jika dilihat dari sumber data yang digunakannya, tidak mengenal adanya dualisme jenis data seperti yang dikenal pada lingkungan metode penelitian secara umum, khususnya penelitian ilmu-ilmu sosial (social science) meskipun pada perkembangannya metode penelitian ilmuilmu sosial juga merupakan pengembangan dari metode penelitian yang pada awalnya menjadi tradisi peneliti ilmu-ilmu alam (eksakta). Data yang digunakan di dalam penelitian hukum, khususnya pada tradisi common law, hanya dikenal dengan legal source yang jika diterjemahkan ke bahasa Indonesia berarti sumber hukum. Sedangkan pembedaan jenis dan tingkatantingkatannya yaitu: primary source, secondary source, dan judicial source.

Dengan demikian, jenis data penelitian hukum yang dikenal oleh para penstudi hukum di Indonesia selama ini yaitu berupa data primer, sekunder, dan tersier, yang kesemuanya merupakan hasil adopsi/pinjaman dari kategorisasi jenis data yang digunakan oleh tradisi ilmu-ilmu sosial. Alatalat untuk pengumpulan data yang biasa digunakan antara lain:

a) Penelusuran literatur hukum. ${ }^{30}$

Pada penelitian hukum doktrinal/normatif, penggunaan data sekunder menjadi sangat dominan. Bahkan data sekunder tersebut dikualifikasikan berdasarkan kekuatan mengikatnya, yaitu:

1) Sumber/bahan hukum primer (mandatory primary sources);

\footnotetext{
${ }^{30}$ Di dalam tradisi penelitian sosial penelusuran literatur hukum ini dikategorikan sebagai alat pengumpul data yang disebut dengan penelitian kepustakaan (library research) dan jenis data yang diperoleh adalah data sekunder. Namun yang membedakannya di dalam penelitian hukum, penelitian kepustakaan tujuan utamanya adalah mencari peraturan perundang-undangan hukum positif dan putusan-putusan pengadilan sebagai bahan hukum primer, yang tentunya tidak ditemukan pada penelitian ilmu sosial pada umumnya.
} 
2) Sumber/bahan hukum sekunder (secondary sources); dan

3) Sumber/bahan hukum tersier.

4) Pengamatan atau observasi;

5) Wawancara (interview); dan

6) Kuesioner.

Di dalam tradisi penelitian hukum barat, bahan-bahan penelitian hukum (legal research materials) yang dikenal yaitu: primary sources (statutory law, case law), secondary sources (books, journals, etc.), finding aids and indexes. . $^{31}$

\section{Mengenai Sistematika Suatu Penelitian Hukum}

Di salam tradisi pemikiran ilmiah bahkan penelitian ilmiah dikenal istilah Logico-hypotetico-verivicatie, Namun bagaimanakah relevansinya terhadap sistematika penelitian hukum.

Menurut C.F.G. Sunaryati Hartono ${ }^{32}$, penelitian hukum harus melalui dan melakukan tahapan-tahapan sebagai berikut:

a) mencari dan mengklasifiksikan fakta-fakta;

b) mengadakan klasifikasi tentang masalah hukum yang diteliti;

c) (kadang-kadang) mengadakan penelitian historis sosiologis maupun historis yuridis mengenai masalah hukum yang diteliti;

d) mengadakan analisis hukum atau/dan analisis interdisipliner dan multidisipliner;

e) agar lebih mendalam lagi maka peneliti hukum seyogyanya mengadakan perbandingan hukum;

f) lebih lengkap lagi, apabila peneliti juga membandingkan latar belakang filsafat dan sosial dari sistem hukum yang dibandingkan;

g) menarik kesimpulan; dan

h) mengajukan saran-saran.

\section{Penutup}

Ilmu hukum (jurisprudence) dan segala sub kajian yang mendampinginya di dalam keluarga besar kajian tentang hukum, terlepas dari kontroversinya sebagai sebagai suatu disiplin ilmu yang mandiri dan khas (sui generis), bagian dari ilmu humaniora maupun ilmu sosial, sebagaimana ilmu pengetahuan alam (eksakta) dan ilmu-ilmu sosial yang telah memiliki tempat yang tak terbantahkan di ranting-ranting pohon ilmu. Ilmu hukum harus diakui memiliki metode penelitian yang khas sekaligus unik, baik dilihat dari kepentingan/kegunaan dilakukannya suatu penelitian

\footnotetext{
${ }^{31}$ Colleen Kristl Pauwels., Op.Cit, hlm. 8.

${ }^{32}$ C.F.G. Sunaryati Hartono, Op.Cit, hlm. 44-45.
} 
di bidang hukum, baik teoritis maupun praktis, atau dari cara melihat ilmu hukum sebagai disiplin yang bersifat preskriptif dan terapan, maupun dari sudut pandang prilaku manusia yang berkaitan dengan eksistensi hukum.

Para penstudi hukum seyogyanya menyadari arti pentingnya penelitian hukum yang menjadi otoritasnya, bahkan dihimbau untuk tidak meninggalkannya, yaitu penelitian hukum normatif/doktrinal, baik dari sudut pandang pendekatan commom law system (statutes approach, case approach, historical approach, comparative approach dan conceptual approach) maupun dari sudut pandang bentuk-bentuknya (penelitian asasasas hukum, sinkronisasi peraturan perundang-undangan, dan lain-lain) yang selama ini dijadikan pegangan oleh para penstudi hukum di Indonesia dan cenderung dimaksudkan untuk kepentingan akademis, sebaiknya harus dipandang dengan rasa bangga terhadap keberagaman dan kekhasan terhadap fenomena penelitian hukum di Indonesia. Mengingat hal yang lebih penting adalah pengetahuan dan kesadaran para penstudi hukum itu sendiri terhadap adanya perbedaan-perbedaan ini. Lebih dari itu, hal yang terpenting adalah ketepatan saat menentukan pilihan terhadap jenis dan metode mana yang terbaik atau paling sesuai (most appropriate) bagi penelitian yang akan dilakukannya, tentunya hal tersebut mengacu kepada kegunaan/tujuan dan hasil akhir yaitu terjawabnya permasalahan yang melatarbelakangi/menginspirasikan dilakukannya suatu penelitian hukum tertentu, kemudian yang tidak kalah penting adalah menjadi lebih berkembangnya kajian keilmuan hukum dan terselesaikannya masalahmasalah hukum baik sifatnya konkret (perkara hukum/legal disputes) maupun permasalahan pembangunan hukum di masa mendatang, yang tentunya semua itu berkat bantuan metode penelitian hukum sebagai alat sekaligus keterampilan yang menuntut kemahiran para penggunanya dalam memanfaatkannya.

Terakhir, mengenai masalah perbedaan konsepsi-konsepsi dan pengertian-pengertian di dalam studi tentang penelitian hukum diberbagai fakultas hukum dan sekolah tinggi hukum khususnya untuk kepentingan akademis (skipsi, tesis, dan disertasi), pertanyaan utamanya adalah perlu atau tidaknya suatu keseragaman itu diwujudkan, atau membiarkan itu semua dengan berpedoman kepada keyakinan masing-masing peneliti hukum mengenai cara yang dianggapnya paling baik 


\section{Daftar Pustaka}

\section{A. Buku}

Banakar, Reza and Max Traves (ed), 2005. Theory and Method in SocioLegal Research: A Series published for The ONATI institute for the sociology of law, Oxford and Portland Oregon: Hart Publishing.

Dirjosisworo, Soedjono, 2002. Memorandum Hukum, Jakarta: Ghalia Indonesia.

Friedman, Lawrenc M., 1975. The Legal System; the social science perspective, New York: Russel Sage Foundation. , 2001. American Law: An Introduction, 2nd edition, diterjemahkan oleh: Wisnu Basuki, American Law: An Introduction, 2nd edition-Hukum Amerika Sebuah Pengantar Jakarta: PT Tata Nusa.

Hartono, C.F.G. Sunaryati, 1994. Penelitian Hukum di Indonesia pada Akhir Abad ke-20, Bandung: Penerbit Alumni.

Hayton, DJ, (ed)., 2002. Laws futures, Oxford: Hart Publishing.

Lloyd, 1985. Lord; of Hampstead and MDA Freeman, Lloyd's Introduction to Jursprudence, 5th ed, London: Stevens \& Sons.

Qadir, C,A, (ed)., 1988. Ilmu Pengetahuan dan Metodenya, Jakarta: Yayasan Obor Indonesia.

Soekanto, Soerjono, dan Sri Mamudji, 2001. Penelitian Hukum Normatif; Suatu Tinjauan Singkat, Jakarta: RajaGrafindo Persada. , 1986, Pengantar Metode Penelitian Hukum, Jakarta: UI Press.

Waluyo, Bambang, 2002. Penelitian Hukum Dalam Praktek, Jakarta: Sinar Grafika.

Wignjosoebroto, Soetandyo, 2002. Hukum; Metode, dan Dinamika Masalahnya, Jakarta: ELASAM dan HUMA.

Zed, Mestika, 2004. Metode Penelitian Kepustakaan, Jakarta: Yayasan Obor Indonesia.

\section{B. Jurnal}

Cheng Han Tan et, al., Legal Education in Asia, Asian Journal of Comparative Law Volume 1, Issue 12006 Article 9.

Eleanor Wong, Designing a Legal Skills Curriculum For an Asian Law School: Lessons in Adaptation, Asian Journal of Comparative Law Volume 1, Issue 12006 Article 5.

Eleanor Wong, Designing a Legal Skills Curriculum For an, Asian Law School: Lessons in Adaptation, Asian Journal of Comparative Law, Volume 1, Issue 12006 Article 5. 
Hikmahanto Juwana Hikmahanto Juwana, Penulisan Hukum dan Riset Dokumentasi Hukum (Hand Out Presentation) disampaikan pada Pelatihan Khusus Profesi Advokat 1 Mei 2007 kerjasama antara PERADI, FH UNTAR, AKHI, dan HKHPM di Universitas Taruma Negara Jakarta.

Hikmahanto Juwana, Legal Education Reform in Indonesia, Asian Journal of Comparative Law, Volume 1, Issue 12006 Article 8.

Javaid Rehman, Institutions of International Law and the Development of Regional Forum for Peaceful Dialogue in South Asia, Asian Journal of Comparative Law, Volume 1, Issue 12006 Article 16.

Margaret Fordham, Comparative Legal Traditions - Introducing the Common Law to Civil Lawyers in Asia, Asian Journal of Comparative Law, Volume 1, Issue 12006 Article 11.

\section{Web atau Internet}

Lancaster University Law School di alamat situs: http://www.lancs.ac.uk/fass/law/prospective/postgrad/sociolegal.html.

University College London (UCL) dengan nama " Center for Empirical Legal Studies", lihat alamat situs: http://w ww.ucl.ac.uk/laws/sociolegal/index.shtml.

University of Oxford, dengan nama "Socio-Legal Studies", Lihat situs: http://www.adm in.ox.ac.uk/postgraduate/caz/socleg.shtml. 